\title{
The Possibilities of Using Common Buckwheat in Phytoremediation of Mineral and Organic Soils Contaminated with $\mathrm{Cd}$ or $\mathrm{Pb}$
}

\author{
Jolanta Domańska $^{1, *(D)}$, Danuta Leszczyńska ${ }^{2}\left(\mathbb{D}\right.$ and Aleksandra Badora ${ }^{1}$ (D) \\ 1 Sub-Department of Quality and Standardization of Plant Materials, Department of Agricultural and \\ Environmental Chemistry, University of Life Sciences in Lublin, Akademicka 15, 20-950 Lublin, Poland; \\ aleksandra.badora@up.lublin.pl \\ 2 Department of Cereal Crop Production, Institute of Soil Science and Plant Cultivation, \\ State Research Institute, Czartoryskich 8, 24-100 Puławy, Poland; leszcz@iung.pulawy.pl \\ * Correspondence: jolanta.domanska@up.lublin.pl
}

Citation: Domańska, J.; Leszczyńska, D.; Badora, A. The Possibilities of Using Common Buckwheat in Phytoremediation of Mineral and Organic Soils Contaminated with Cd or $\mathrm{Pb}$. Agriculture 2021, 11, 562. https://doi.org/10.3390/ agriculture11060562

Academic Editor: Ryusuke Hatano

Received: 12 May 2021

Accepted: 18 June 2021

Published: 19 June 2021

Publisher's Note: MDPI stays neutral with regard to jurisdictional claims in published maps and institutional affiliations.

Copyright: (c) 2021 by the authors. Licensee MDPI, Basel, Switzerland. This article is an open access article distributed under the terms and conditions of the Creative Commons Attribution (CC BY) license (https:/ / creativecommons.org/licenses/by/ $4.0 /)$.

\begin{abstract}
The results of this study provided accurate guidance on the possibility of using common buckwheat (Fagopyrum esculentum Moench) in phytoremediation practices for mineral soil or organic soils contaminated with $\mathrm{Cd}$ or $\mathrm{Pb}$. Based on a model pot experiment, the tolerance of buckwheat to elevated contents of cadmium and lead in organic and mineral soils was examined. The soils were differentiated into neutral and acidic, and amended with metals at doses of $10 \mathrm{mg} \mathrm{Cd} \mathrm{kg}^{-1} \mathrm{DM}$ and $100 \mathrm{mg} \mathrm{Pb} \mathrm{kg}^{-1} \mathrm{DM}$ of soil. The growth, development, biomass, translocation coefficient, and tolerance index (TI) of the tested plants were examined. The use of metals caused a weakening of plant growth and development, as well as intensified chlorotic and necrotic changes to the buckwheat leaves. The application of Cd caused a statistically significant decrease in shoot biomass. The plants growing in organic acidic soil were most vulnerable to $\mathrm{Cd}$ toxicity. The (TI) values confirm the generally low tolerance of buckwheat to $\mathrm{Cd}$, except for the treatment in organic neutral soil, and the high tolerance of this plant to $\mathrm{Pb}$ in all the studied soils.
\end{abstract}

Keywords: common buckwheat biomass; cadmium; lead; phytoremediation; tolerance index; translocation coefficient; mineral soil; organic soil; $\mathrm{pH}$

\section{Introduction}

Common buckwheat is a plant with many uses, and studies concerning the tolerance of this plant to soil metal in polluted areas are essential, both in phytoremediation practices and, in crop production planning and management. Understanding the capability of this plant to absorb toxic metals such as $\mathrm{Cd}$ and $\mathrm{Pb}$ from different soils is also important in the context of ecology and public health safety. Buckwheat contains antioxidants (routine, quercetin, and others) and has pro-health effects, therefore this plant is used in medicine.

The problem of environmental pollution with heavy metals, such as $\mathrm{Cd}, \mathrm{Pb}, \mathrm{Cu}$, $\mathrm{Ni}, \mathrm{Zn}$, and others, and their toxicity to living organisms has attracted the attention of researchers [1,2]. Soil pollution is particularly relevant in areas surrounded by various industrial plants, metallurgical plants, steel mills, combined heat and power plants. Moreover, the constantly high level of world metal mining, processing, and the resulting waste are a source of environmental pollution [3]. For this reason, large areas of soils in the world within industrial regions, are restricted for food production due to the maximum permissible levels of metals in plants. Appropriate recommendations were set by EU regulation [4]. Cadmium and lead are currently considered to be toxic metals, whose presence in the soil in higher amounts than the natural biogeochemical background may threaten the natural environment. Plants, which are part of this environment in the soil-plantanimal-human system, as a result of taking up metal from the soil contribute to its further circulation $[5,6]$. Some plant species have developed mechanisms that allow an increased 
uptake of a toxic components without harming their body, but the risk of harmfulness or toxicity in subsequent links of the trophic chain, remains. For this reason, research that focuses on remediation methods for soils contaminated with metals is often carried out. Much attention is particularly paid to two phytoremediation techniques: phytoextraction and phytostabilization $[7,8]$. In the course of phytoextraction, the soil is cleaned of excess toxic metals by removing plants that have accumulated them in their biomass. The goal of phytostabilization is to limit the mobility and bioavailability of metals by growing plants that absorb them and retain them in their root system. In addition, the vegetation cover limits the spread of soil particles with contaminants into the ecosystem.

Scientists are conducting research to assess the potential of common buckwheat for phytoremediation [9]. Harada and Hatanaka [10] found higher concentrations of cadmium in the plants of the Polygonaceae family, compared to other studied plant families. Confirmation of the usefulness of buckwheat in phytoremediation techniques may have practical significance. When assessing a plant, many factors and the complexity of the process should be considered.

Common buckwheat Fagopyrum esculentum Moench (Polygonaceae), which was the subject of the present study, is an annual, dicotyledonous plant with a very short vegetation period (70-90 days). Buckwheat is distinguished by its good use of nutrients contained in the soil and does not require intensive mineral fertilization. It has a high resistance to pests and diseases, and therefore does not require special chemical protection. The aerial parts of buckwheat, especially the seeds, are used mainly for food purposes. Due to the presence of antioxidants (routine, quercetin, and others) and its pro-health effects, this plant is used in medicine.

Our study intended to show (i) how the presence of $\mathrm{Cd}$ and $\mathrm{Pb}$ in different soil types affects the growth of common buckwheat; (ii) if the growth of the plant and the biomass obtained, and thus the tolerance for a given metal, changes under the influence of the presence of another metal ion; and (iii) how experimental factors (soil, metals, $\mathrm{pH}$ ) affect the process of transporting metals from the roots to the aerial parts of the studied plant.

The objective of the study was to determine, based on a model pot experiment, the tolerance of buckwheat to $\mathrm{Cd}$ or $\mathrm{Pb}$, and its usefulness for the phytoremediation of organic and mineral soils. The soils differed in $\mathrm{pH}$ value (acidic or neutral) and in organic matter content. The buckwheat growth, development, biomass, and certain chemical indicators, depending on soil type, $\mathrm{pH}$, and $\mathrm{Cd}$ or $\mathrm{Pb}$ addition, were determined.

\section{Materials and Methods}

\subsection{Soils}

The research was based on the results obtained in a two-year pot experiment carried out on two organic and mineral soils, with different $\mathrm{pH}$ values. The uncontaminated soils were sampled in agricultural areas of Lubelskie region (Poland). Soil material was taken from the surface layer $(0-20 \mathrm{~cm})$. The following soils, according to Polish Soils Classification [11], were used to fill pots:

Podzolic soils, Typical podzolic soils—developed from light loamy sand, Organic soils, (fibric peat soils),

Organic soils, (sapric peat soils).

The neutral reaction of mineral soil was obtained by applying calcium carbonate $\left(\mathrm{CaCO}_{3}\right)$ to mineral acidic soil, so as to double the hydrolytic acidity. The main agrochemical properties of the soils, determined before the experiment started, are listed in Table 1. 
Table 1. Agrochemical characteristics of soils used for the experiment.

\begin{tabular}{|c|c|c|c|c|}
\hline Parameter & & Mineral Neutral/Acidic & Organic Neutral & Organic Acidic \\
\hline Particle size distribution: & & & \multirow{4}{*}{ not determined } & \multirow{4}{*}{ not determined } \\
\hline $1-0.1 \varnothing \mathrm{mm}$ & $\%$ & 74 & & \\
\hline $0.1-0.2 \varnothing \mathrm{mm}$ & $\%$ & 18 & & \\
\hline$<0.02 \varnothing \mathrm{mm}$ & $\%$ & 8 & & \\
\hline $\mathrm{pH}_{\mathrm{KCl}}$ & & $7.2 / 4.6$ & 7.2 & 3.6 \\
\hline Organic C & $\%$ & 1.32 & 18.7 & 64.0 \\
\hline \multicolumn{5}{|l|}{ Total: } \\
\hline $\mathrm{Pb}$ & $\mathrm{mg} \mathrm{kg}^{-1}$ & 5.49 & 16.65 & 20.98 \\
\hline $\mathrm{Cd}$ & $\mathrm{mg} \mathrm{kg}^{-1}$ & 0.10 & 0.43 & 0.30 \\
\hline $\mathrm{Zn}$ & $\mathrm{mg} \mathrm{kg}^{-1}$ & 20.00 & 44.50 & 80.00 \\
\hline
\end{tabular}

\subsection{Pot Experiment}

The soil material was transferred to $5 \mathrm{dm}^{3}$ volume pots. The pots contained $4.8 \mathrm{~kg}$ of organic acidic soil, $5.5 \mathrm{~kg}$ of organic neutral soil, and $6.4 \mathrm{~kg}$ of mineral soil. Each soil was treated with $10 \mathrm{mg} \mathrm{kg}^{-1}$ dry mass $(\mathrm{DM}) \mathrm{Cd}\left(\mathrm{Cd}\left(\mathrm{NO}_{3}\right)_{2}\right)$ and $100 \mathrm{mg} \mathrm{kg}^{-1} \mathrm{DM} \mathrm{Pb}$ $\left(\mathrm{Pb}\left(\mathrm{NO}_{3}\right)_{2}\right)$. Metals were introduced once before sowing. Metal rates were applied to the soils according to the following scheme:

1. $0=$ control with no metal addition,

2. $\mathrm{Pb}=\mathrm{Pb}(\mathrm{II})$ in an amount of $100 \mathrm{mg} \mathrm{kg}^{-1} \mathrm{DM}$,

3. $\mathrm{Cd}=\mathrm{Cd}(\mathrm{II})$ in an amount of $10 \mathrm{mg} \mathrm{kg}^{-1} \mathrm{DM}$.

All soils were fertilized with $\mathrm{N}, \mathrm{P}$, and $\mathrm{K}$ using mineral salts: $\mathrm{NH}_{4} \mathrm{NO}_{3}, 0.10 \mathrm{~g} \mathrm{~N} \mathrm{~kg}^{-1}$ soil; $\mathrm{CaHPO}_{4}, 0.07 \mathrm{~g} \mathrm{P} \mathrm{kg}^{-1}$ soil; and $\mathrm{KCl}, 0.15 \mathrm{~g} \mathrm{~K} \mathrm{~kg}^{-1}$. The $\mathrm{NH}_{4} \mathrm{NO}_{3}$ dose was divided into two equal parts and applied to all pots before and after sowing. During the experiment, the mineral soil humidity was adjusted to $60 \%$ of maximum water capacity, and $80 \%$ in the case of organic soils, by keeping water in pots at a constant weight.

Common buckwheat (Fagopyrum esculentum Moench) was a follow-up crop to rapeseed (Brassica napu L.). Seeds of the test plant were sown on 15 June. To prevent incomplete seedling emergence for the experiment, more seeds were sown than the number of plants planned for each pot. After successful germination, seedlings were thinned to 10 plants per pot. Plants were kept under natural light at all times. Plant growth and development were observed every day in the growing season. Plants were harvested during the flowering phase by cutting out the aerial parts (shoots). After harvesting, plants roots were separated from the soil and rinsed with deionized water. Then, the aboveground biomass (shoots) and roots were weighed. The plant samples were oven-dried to determine their dry matter.

\subsection{Soil and Plant Chemical Analyses}

The collected soil samples were air-dried, then ground in a porcelain mortar and sieved through 1-mm mesh. The soil samples were determined for:

- mineral soil granulometric composition using Casagrande's aerometric method with Prószyński's modifications,

- $\mathrm{pH}$, potentiometry in $1 \mathrm{M} \mathrm{KCl}$,

- $\quad$ organic matter $\left(\mathrm{C}_{\mathrm{org}}\right)$ ), Tiurin's method,

- contents of organic matter in organic soils, by annealing,

- contents of $\mathrm{Cd}$ and $\mathrm{Pb}$ in soils, analyzed after digesting the soil samples in the mixture of concentrated acids $\mathrm{HCl}$ and $\mathrm{HNO}_{3}$ in the ratio of 3:1 (aqua regia).

Individual metals $(\mathrm{Cd}$ and $\mathrm{Pb})$ were quantified in solution by means of flame atomic absorption spectrometry (AAS) on a Hitachi Z-8200 apparatus.

Cadmium and lead contents were determined in plant samples by applying the AAS technique after plant material digestion in concentrated $\mathrm{H}_{2} \mathrm{SO}_{4}$ with the addition of $\mathrm{H}_{2} \mathrm{O}_{2}$. 


\subsection{Data Analysis}

The trial was arranged in a randomized blocks method. The design of the experiment included six pots in four replicates in mineral soil, and six pots in four replicates in organic soils.

Data obtained from experiments were statistically processed by means of variance analysis with Tukey confidence intervals. Differences were considered to be significant at $p=0.05$ and highly significant at a $p=0.01$ level of significance.

The tested plants were calculated for two indices (TI and TF) recommended for the evaluation of plants for phytoremediation. The tolerance index (TI) is the ratio between a biomass of treated plants $\left(\mathrm{g} \mathrm{DM} \mathrm{pot}^{-1}\right)$ and the biomass of control plants $\left(\mathrm{g} \mathrm{DM} \mathrm{pot}^{-1}\right)$. It specifies the degree of inhibition of plant growth in $\mathrm{Cd}$ or $\mathrm{Pb}$ contaminated soil and is helpful for evaluating the tolerance of common buckwheat to an excess of metals when growing in contaminated soils.

The translocation factor (TF) was calculated as the ratio of metal concentration $\left(\mathrm{mg} \mathrm{kg}^{-1}\right)$ in the shoots and roots of the tested plant $\left(\mathrm{TF}=\mathrm{C}_{\text {shoots }} / \mathrm{C}_{\text {roots }}\right)$. In our experiment, this allowed evaluating the buckwheat's ability to translocate $\mathrm{Cd}$ and $\mathrm{Pb}$ from roots to aerial parts when the plant was grown in mineral or organic soils at different $\mathrm{pH}$.

\section{Results}

\subsection{The Growth of Common Buckwheat Plants}

Common buckwheat was sown in mid-June after harvesting spring rape. Plant emergence was even in all treatments. Plants from treatments in organic soils were slightly higher and better developed than ones from the treatments in mineral soil. After 2 weeks, plants grown in organic neutral and organic acidic soils were $12 \mathrm{~cm}$ and $7 \mathrm{~cm}$ high, respectively, and showed no symptoms of chlorosis. Common buckwheat sown in mineral soils grew slower compared to treatments in organic soils. The lamina of the crops, however, were larger and more saturated by chlorophyll (dark green color of leaves), particularly in the $\mathrm{Pb}$ treatment. At the edges older plant leaves, mild necrotic changes, often combined with chlorosis in $\mathrm{Cd}$ and $\mathrm{Pb}$ treatments, were observed. In plants grown in acidic mineral soil, purple discolorations were also found. The generative phase first began in plants in organic neutral soil, and was later in plants in mineral acidic soil. Plants growing in the soil developed from high peat (organic acidic), had less generative shoots than the plants in other treatments. Although buckwheat is a plant that tolerates low soil $\mathrm{pH}$ well, its growth in acidic soils, both mineral and organic, was slower, and the impact of metals was more severe. In the $\mathrm{Pb}$ treatment, the leaves underwent curling toward the center of the leaf blade, and deformations occurred. The weakest growth of plants was observed in acidic soils contaminated with cadmium. In the full flowering phase, just before the buckwheat harvest (end of July), yellowing and dropping of the oldest leaves were observed in organic soils.

\subsection{Effects of Cadmium and Lead on Common Buckwheat Shoot Biomass}

Experimental factors (type of soil and $\mathrm{pH}$, metal addition) significantly modified the aerial (shoots) biomass (g DM pot ${ }^{-1}$ ) of the tested plants (Figure 1). Significant interactions between soil and $\mathrm{pH}$, as well as soil and cadmium, used in the experiment were also recorded. In organic soil, the average biomass of buckwheat shoots was higher $\left(13.3 \mathrm{~g} \mathrm{pot}^{-1}\right)$ than in mineral soil $\left(11.3 \mathrm{~g} \mathrm{pot}^{-1}\right)$. The soil $\mathrm{pH}$ was also a factor that significantly affected plant growth. In neutral soils, the growth of the buckwheat shoots was faster than in acidic ones, which resulted in a two-fold increase in biomass $\left(16.6 \mathrm{~g} \mathrm{pot}^{-1}\right)$ compared to the acidic soil $\left(8.0 \mathrm{~g} \mathrm{pot}^{-1}\right)$. 

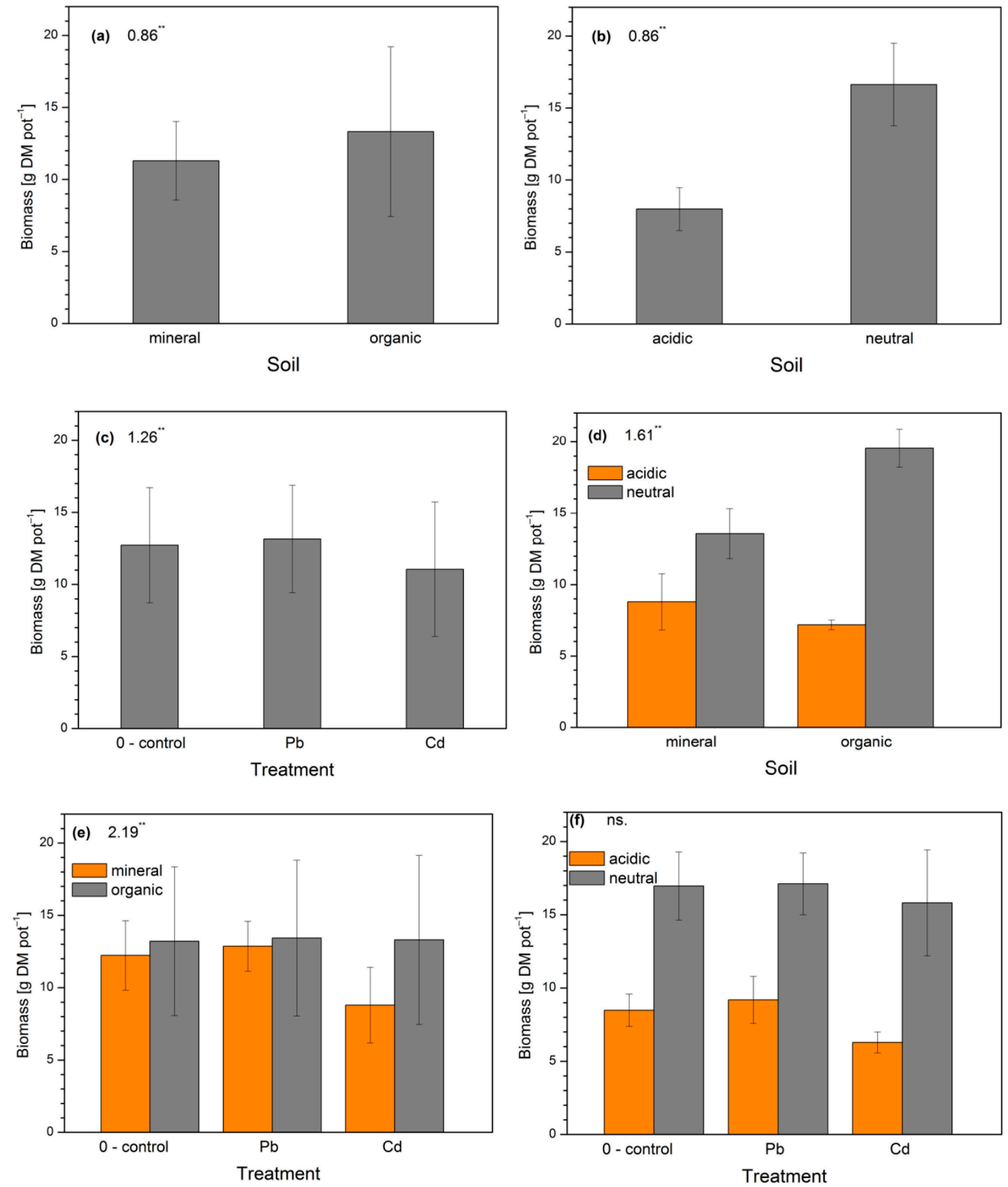

Figure 1. Mean aerial biomass of Fagopyrum esculentum (g DM pot ${ }^{-1}$ ). (a-f), sequence of subfigures. LSD $p=0.01 * *$, ns., non-significant (A, soil; $\mathrm{B}$, soil reaction; $\mathrm{C}$, metal; $\mathrm{AB}$, soil, soil reaction; $\mathrm{AC}$, soil, metal; $\mathrm{BC}$, soil reaction, metal). $\mathrm{A} 0.86^{* *}$, B $0.86^{* *}, \mathrm{C} 1.26^{* *}, \mathrm{AB} 1.61^{* *}, \mathrm{AC} 2.19^{* *}, \mathrm{BC}$ ns.

The effect of cadmium on the average biomass of the tested plant shoots was also significant. In the treatment with $\mathrm{Cd}$ addition, the obtained biomass amounted to, on average, $11.1 \mathrm{~g} \mathrm{per} \mathrm{pot}^{-1}$, while in the control to $12.7 \mathrm{~g}$ per pot $^{-1}$ ).

The soil type and its reaction differentiated the aerial biomass of common buckwheat in the following, decreasing order: organic neutral $>$ mineral neutral $>$ mineral acidic $>$ organic acidic. With regard to the control $\left(12.2 \mathrm{~g} \mathrm{pot}^{-1}\right)$, a significant buckwheat biomass decrease also occurred in the $\mathrm{Cd}$ treatment in mineral soil $\left(8.8 \mathrm{~g} \mathrm{pot}^{-1}\right)$, while in the case of " $\mathrm{Pb}$ " treatments (both mineral and organic soils) and the " $\mathrm{Cd}$ " treatment in organic soil 
no significant dependence of soil type on biomass amount was confirmed. Moreover, no significant influence of $\mathrm{pH}$ (acidic, neutral) on buckwheat shoot biomass in treatments with metals ("Cd", " $\mathrm{Pb}$ ") was found.

\subsection{Effects of Cadmium and Lead on Common Buckwheat Root Biomass}

The type of soil, in relation to the roots, unlike the above-ground parts of buckwheat, did not significantly affect the dry mass yield $\left(\mathrm{g} \mathrm{DM} \mathrm{pot}^{-1}\right)$, Figure 2 . However, the soil $\mathrm{pH}$ and the metals proved to be a factor significantly modifying the underground (roots) $\mathrm{DM}$ of the buckwheat. For a neutral reaction, the root biomass was almost twice as high as in acidic soils (1.5 $\mathrm{g} \mathrm{pot}^{-1}$ and $0.8 \mathrm{~g} \mathrm{pot}^{-1}$, respectively).
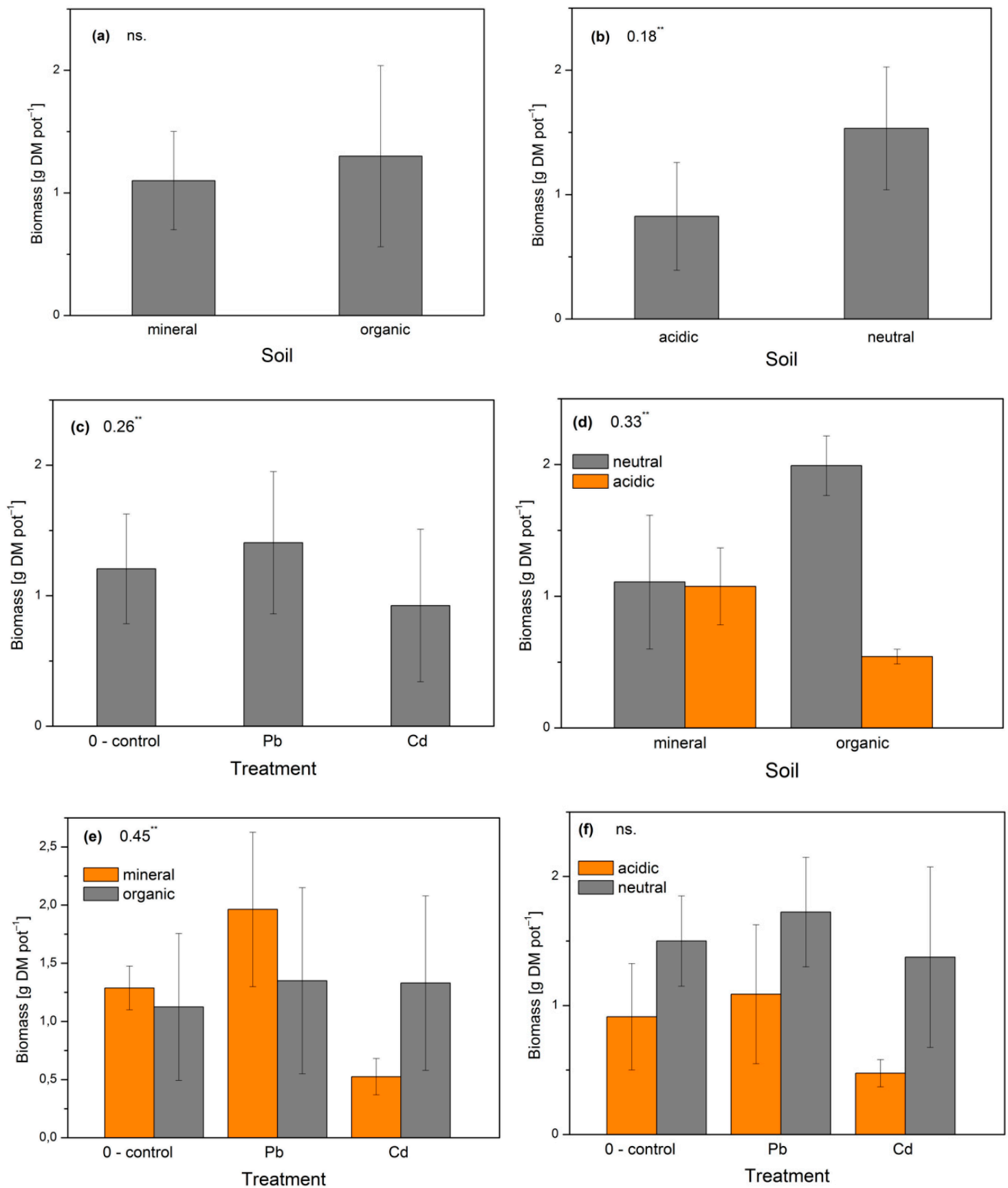

Figure 2. Mean underground biomass of Fagopyrum esculentum $\left(\mathrm{g} \mathrm{DM} \mathrm{pot}^{-1}\right)$. (a-f)—sequence of subfigures. LSD $p=0.01 * *$, ns.: non-significant (A, soil; B, soil reaction; $C$, metal; $A B$, soil, soil reaction; AC, soil, metal; BC, soil reaction, metal). A ns., B $0.18^{* *}, \mathrm{C} 0.26^{* *}, \mathrm{AB} 0.33^{* *}, \mathrm{AC} 0.45^{* *}, \mathrm{BC}$ ns. 
The use of lead resulted in an increase in root biomass $\left(1.4 \mathrm{~g} \mathrm{pot}^{-1}\right)$, while cadmium reduced its content $\left(0.9 \mathrm{~g} \mathrm{pot}^{-1}\right)$ significantly compared to the control $\left(1.2 \mathrm{~g} \mathrm{pot}^{-1}\right)$.

The soil type and its reaction were factors that significantly affected root biomass only in organic soils. In organic neutral soil, the growth of the buckwheat roots was better than in organic acidic soil, which resulted in an almost four-fold increase in biomass, as compared to the acidic soil.

The stimulating effect of lead at a dose of $100 \mathrm{mg} \mathrm{kg}^{-1} \mathrm{DM}$ of soil on the biomass of buckwheat roots was noted both in mineral and organic soils, but a highly significant increase $\left(2.9 \mathrm{~g} \mathrm{pot}^{-1}\right)$ compared to the control $\left(1.3 \mathrm{~g} \mathrm{pot}^{-1}\right)$ was recorded only in mineral soil. On the other hand, cadmium significantly reduced the root biomass in mineral soil compared to the control.

No significant influence of $\mathrm{pH}$ (acidic, neutral) and metals (" $\mathrm{Cd}^{\prime}$, " $\mathrm{Pb}$ ") on buckwheat root biomass was found.

\subsection{Tolerance Index (TI)}

Tolerance index (TI) indicates the plant's tolerance to toxic metals and helps to assess the usefulness of the plant in phytoextraction (Table 2). The calculated TI values showed a different tolerance of buckwheat relative to cadmium and lead. The lowest TI values, 0.61 and 0.29 for buckwheat shoots and roots, respectively, were recorded in $\mathrm{Cd}$ amended mineral acidic soil. Similarly, in the case of neutral mineral soil contaminated with $\mathrm{Cd}$, low index values of 0.74 in shoots and 0.54 in roots were found. In the remaining treatments $\left(" \mathrm{~Pb}^{\prime}\right)$, the TI was relatively high, and ranged from 0.99 to 1.23 . The index value, $\mathrm{TI}=0.91$, implicating a slightly reduced tolerance of plant shoots, was also reported for organic acidic soil in the $\mathrm{Cd}$ treatment. The obtained data confirm the generally low tolerance of buckwheat in relation to $\mathrm{Cd}$, except for plants from the treatments in organic neutral soil, and the high tolerance to $\mathrm{Pb}$ in both mineral and organic soils.

Table 2. The indices of Fagopyrum esculentum tolerance to $\mathrm{Cd}$ and $\mathrm{Pb}$ when grown in different soils.

\begin{tabular}{|c|c|c|c|c|c|}
\hline \multicolumn{2}{|c|}{ Treatment } & \multicolumn{2}{|c|}{ TI * } & \multicolumn{2}{|c|}{$\mathrm{TF}^{* *}$} \\
\hline Soil & Metal & Shoots & Roots & $\mathrm{Cd}$ & $\mathrm{Pb}$ \\
\hline \multirow{3}{*}{$\begin{array}{l}\text { Mineral } \\
\text { acidic }\end{array}$} & 0 & 1.00 & 1.00 & 4.50 & 0.64 \\
\hline & $\mathrm{Pb}$ & 1.15 & 1.23 & 4.56 & 0.04 \\
\hline & $\mathrm{Cd}$ & 0.61 & 0.29 & 1.74 & 1.16 \\
\hline \multirow{3}{*}{$\begin{array}{c}\text { Mineral } \\
\text { neutral }\end{array}$} & 0 & 1.00 & 1.00 & 1.21 & 0.62 \\
\hline & $\mathrm{Pb}$ & 0.99 & 1.04 & 2.39 & 0.21 \\
\hline & $\mathrm{Cd}$ & 0.79 & 0.54 & 1.77 & 0.83 \\
\hline \multirow{3}{*}{$\begin{array}{c}\text { Organic } \\
\text { acidic }\end{array}$} & 0 & 1.00 & 1.00 & 2.78 & 0.77 \\
\hline & $\mathrm{Pb}$ & 0.99 & 1.10 & 2.51 & 0.56 \\
\hline & $\mathrm{Cd}$ & 0.91 & 1.16 & 5.11 & 0.69 \\
\hline \multirow{3}{*}{$\begin{array}{c}\text { Organic } \\
\text { neutral }\end{array}$} & 0 & 1.00 & 1.00 & 0.91 & 0.45 \\
\hline & $\mathrm{Pb}$ & 1.03 & 1.23 & 0.60 & 0.07 \\
\hline & $\mathrm{Cd}$ & 1.05 & 1.19 & 0.47 & 0.26 \\
\hline
\end{tabular}

\subsection{Translocation Factor (TF)}

The translocation factor (TF) is fundamental for the evaluation a plant's usefulness in phytostabilization. This parameter was very high for $\mathrm{Cd}$ in buckwheat in most of treatments, ranging from 1.21 to 5.11 (Table 2). The exception were the treatments in neutral organic soil, where TF values were low and ranged from 0.07 to 0.26 , which means that the plant transported to the aerial parts between $7 \%$ and $26 \%$ of the cadmium contained in the roots.

Much lower TF values were calculated for lead than for cadmium in buckwheat. Only in plants from acidic mineral soil contaminated with cadmium did the TF for lead exceed 
the threshold value $(\mathrm{TF}<1)$, reaching the level $\mathrm{TF}=1.16$. In other treatments, this parameter was at a much lower level $(0.04-0.83)$ than the required threshold value $(\mathrm{TF}<1)$. The lowest $\mathrm{TF}$ values for lead were found in treatments with the addition of lead (0.04-0.56).

\section{Discussion}

Common buckwheat Fagopyrum esculentum (Polygonaceae) is a plant of many uses. It is grown as a cereal for humans and as a forage crop for livestock, as well as being applied in herbal medicine and beekeeping [12,13]. The areas of research on the non-food use of buckwheat include cleaning the soil of excess metals [14-16]. Common buckwheat is recognized as a hyperaccumulator of $\mathrm{Pb}$ [17]. Similarly, a high ability for $\mathrm{Pb}$ accumulation is displayed by Tartary buckwheat, which can grow in soil with high concentrations of this metal $\left(10,000 \mathrm{mg} \mathrm{kg}^{-1}\right)$ [18]. The high buckwheat capacity for $\mathrm{Pb}^{2+}$ accumulation and the efficiency of the phytoremediation process can be enhanced by the presence of EDTA [19]. The results of the study by Tamura et al. [20] showed that common buckwheat grown in Pb-contaminated soil is able to absorb $8 \mathrm{~g} \mathrm{~Pb} \mathrm{~kg}^{-1}$ dry mass in leaves without significant damage, while in roots $3.3 \mathrm{~g} \mathrm{~Pb} \mathrm{~kg}^{-1}$. Based on these results, the authors proved that common buckwheat can be classified as an Pb-hyperaccumulator. Buckwheat is also known as a $\mathrm{Cu}$ and $\mathrm{Zn}$ accumulator [21]. It has a high $\mathrm{Al}$ bioaccumulation capacity (Al accumulator) and concentrates $\mathrm{Al}$ mainly in its leaves [22,23].

Lu et al. [24] found that the Cd accumulation in the leaves of Tartary buckwheat under $\mathrm{Cd}$ stress was markedly inhibited by an excess of endogenous sulfur, while the $\mathrm{Cd}$ concentration in roots increased significantly. The authors also concluded that the enhanced effect of surplus sulfur on antioxidant factors and antioxidant enzymes may play an important role in balancing the levels of reactive oxygen species in Fagopyrum tataricum leaves and roots.

Cadmium is highly mobile in soils in the $\mathrm{pH}$ range 4.5-5.5. It readily reaches plants through root uptake and translocation to the above-ground parts of plants. This element is mainly taken up by plants from the soil in the form of the ion $\mathrm{Cd}^{2+}$. Its uptake and transport depend on the plant species and genotype. The absorption of this metal increases at higher $\mathrm{Cd}$ content in the soil and at low $\mathrm{pH}$ values. Cadmium accumulation in plants may be also influenced by the presence of $\mathrm{Zn}$ in the soil solution.

Pirzadach et al. [25] revealed that Al-induced oxidative stress affected the growth indices, photosynthetic pigments, osmolytes, Al-uptake, translocation, and physiological attributes of the studied Fagopyrum species. The hyperactivity of antioxidant enzymes played a special role in the protection of buckwheat. The authors stated that the activities of the antioxidant enzymes, i.e., superoxide dismutase, ascorbate peroxidase, guaiacol peroxidase, glutathione reductase, and glutathione-S-transferase, were positively correlated with Al-treatment. Pirzadach et al. believes that Fagopyrum species have potential as a phytoremediation crop for contaminated areas.

Braud et al. [26] noticed that in moderately contaminated soils, despite an increase in the lead extraction rate with citric acid, buckwheat is not a very efficient plant for field $\mathrm{Pb}$ phytoextraction. Furthermore, Alves et al. [27] found buckwheat to be not very promising for $\mathrm{Pb}$-phytoremediation programs.

There are many regions in Europe with large deposits of mine wastes, and many unmanaged sites contaminated with metals. Scientists have suggested that wastelands could be prepared for regular biomass production using metal tolerant vegetation or bioenergy crops (e.g., oilseed rape, buckwheat, willow) [28]. Soils that are polluted by metals and require remediation often surround historical industrial and mining plants. Due to their degradation, they have unfavorable chemical, physico-chemical, or biological properties for crop production. The premise for the use of buckwheat in phytoremediation is the fact that this plant uses soil resources better than other plant species and is able to also satisfy its nutritional requirements in soils less rich in macro- and microelements or in those contaminated by metals. 
Soil type, granulometric composition, organic matter content, sorption properties, $\mathrm{pH}$, and oxidoreductive potential have the greatest influence on the amount of phyto-available heavy metal that forms in the soil. Soil organic matter, in the form of humus compounds, contributes to reducing the amount of heavy metal forms available to plants, thereby producing a crop with reduced heavy metal content. Metal speciation in the soil also could affect the availability and uptake of metals by plants from the soils. The hazard of heavy metals especially increases in contaminated soil with the increase of its most mobile and bioavailable fractions. The studies of Awad et al. [29] revealed that biochar stabilized heavy metals and could reduce their solubility in contaminated soils. The authors stated that acid soluble metals decreased, while the fraction bound to organic matter increased compared to biochar untreated pots.

Wang et al. [18], investigating the mechanisms of $\mathrm{Pb}$ tolerance and hyperaccumulation in Tartary buckwheat leaves, found that differentially expressed genes (DEGs) are involved in the mechanisms of hyperaccumulation, e.g., iron-binding proteins and membrane transport proteins. Scientists $[30,31]$ revealed that the endogenous application of the plant hormone salicylic acid could play a pivotal role in protecting plants suffering from heavy metal stress. The authors emphasized that further studies are needed to detect salicylic acid-responsive genes, proteins, and metabolites affected by heavy metal stress. In addition, the defensive ability of buckwheat FeMT3 protein and the great responsiveness of its promoter to metal ions during exposure were found [32].

In the present study, soil type and $\mathrm{pH}$ were important factors affecting the growth of common buckwheat. The obtained biomass of plant shoots, depending on the type of soil and $\mathrm{pH}$, was significantly decreased, in the following order: organic neutral $>$ mineral neutral $>$ mineral acidic $>$ organic acidic. This sequence proves the sensitivity of Fagopyrum esculentum to acidic conditions, both in organic and mineral soils, which was expressed by the statistically significant two-fold increase in mean biomass of neutral soils $\left(16.6 \mathrm{~g} \mathrm{pot}^{-1}\right)$ compared to acidic soils $\left(8.0 \mathrm{~g} \mathrm{pot}^{-1}\right)$. Despite the fact that buckwheat makes good use of nutrients from light soils, it has lower yields in acidic soils.

In the present study ( $\mathrm{Cd}$ and $\mathrm{Pb}$ treatments), necrotic changes, often combined with chlorosis on buckwheat leaves, were found. Plants grown in acidic mineral soil also had purple discolorations, which may have indicated the lower availability of $\mathrm{P}$ for such a plant. Tuma et al. [33] stated a higher content of $\mathrm{Cd}$ in most treatments, mainly after $\mathrm{CdSO}_{4}$ application, in the bottom yellow leaves than in upper green leaves of Avena sativa $\mathrm{L}$. According to the authors this indicates the accumulation of $\mathrm{Cd}$ in aging tissues and its difficult reutilization.

The highest sensitivity of buckwheat to soil Cd contamination (10 mg Cd kg-1 DM) was found in mineral soil. A significant effect of $\mathrm{Cd}$ in mineral soil on buckwheat shoot biomass decrease $\left(8.8 \mathrm{~g} \mathrm{pot}^{-1}\right)$ in comparison to the control $\left(12.2 \mathrm{~g} \mathrm{pot}^{-1}\right)$ took place. Moreover, cadmium significantly reduced the root biomass in mineral soil compared to the control. In the case of $\mathrm{Pb}$ applied at a dose of $100 \mathrm{mg} \mathrm{kg}^{-1} \mathrm{DM}$ of soil, no harmful effects were found.

In the works of different authors, the overall negative effect of cadmium and lead on the economic yield and biomass of common buckwheat and other plant species was confirmed [34]. The toxicity threshold limits of $\mathrm{Cd}$ for a $10 \%$ reduction in the relative yield of buckwheat, depending on the amount of FYM application, were $6.4-16.0 \mathrm{mg} \mathrm{Cd} \mathrm{kg}^{-1}$ dry matter in buckwheat [35].

In the present study, buckwheat most often met a condition of the plant's suitability for phytostabilization, which is $\mathrm{Pb}$ transport from the roots to the above-ground part of the plant. A higher $\mathrm{Pb}$ translocation coefficient determined for buckwheat $(\mathrm{TF}=1.16)$ occurred in acidic mineral soil contaminated with cadmium.

For Cd, except treatments in neutral organic soil, the TF was at a much higher level than the required threshold value (TF $<1$ ). This parameter in the case of cadmium probably excludes buckwheat as a plant useful for phytostabilization purposes when growing in soil composed of light loamy sand and in organic acidic soil. According to Lou et al. [36] the 
translocation factor (TF) was greater in perennial ryegrass treated with $\mathrm{Cd}$ than with $\mathrm{Pb}$, and the dose of Cd had no effect on TF.

The obtained data confirm that at the applied doses of $\mathrm{Cd}$ and $\mathrm{Pb}$, buckwheat was less tolerant to $\mathrm{Cd}$, except for plants from treatments in organic neutral soil, while it was tolerant to $\mathrm{Pb}$ in both mineral and organic soils. Horbowicz et al. [37] stated that $\mathrm{Cd}^{2+}$ ions are more harmful than $\mathrm{Pb}^{2+}$ for the growth of buckwheat seedlings.

\section{Conclusions}

The above study, carried out in different types of soil, allowed obtaining precise guidelines regarding the possibility of using buckwheat in the remediation practices of mineral soil (Typical podzolic soil) or organic soil (Peat soils) contaminated with $\mathrm{Cd}$ or $\mathrm{Pb}$.

The soil type and its reaction significantly affected the buckwheat growth. The highest biomass of plants was obtained in organic neutral soil and the lowest in acidic neutral soil. Plants growing in organic acidic soil were also most vulnerable to $\mathrm{Cd}$ toxicity.

The TI (tolerance index) data confirmed the generally low tolerance of buckwheat in relation to $\mathrm{Cd}$, except for plants from the treatments in organic neutral soil, and the high tolerance to $\mathrm{Pb}$ in both mineral and organic soils.

On the basis of the translocation factor TF, we can conclude that buckwheat has a high lead phytostabilization potential, while for cadmium it is low. This plant can be considered as a candidate for phytostabilization in $\mathrm{Pb}$-polluted soils.

Author Contributions: J.D., conceptualization; J.D. methodology; J.D., D.L. software; J.D., A.B.; validation; J.D. formal analysis; J.D. investigation; J.D. resources; J.D., D.L., A.B. data curation, J.D. writing-original draft preparation; J.D., D.L., A.B. writing—review and editing; J.D. visualization; A.B. supervision; J.D. project administration. All authors have read and agreed to the published version of the manuscript.

Funding: This research received no external funding.

Conflicts of Interest: The authors declare no conflict of interest.

\section{References}

1. Rahman, Z.; Singh, V.P. The relative impact of toxic heavy metals (THMs) (arsenic (As), cadmium (Cd), chromium (Cr)(VI), mercury $(\mathrm{Hg})$, and lead $(\mathrm{Pb})$ ) on the total environment: An overview. Environ. Monit. Assess. 2019, 191, 419. [CrossRef]

2. Bi, C.; Zhou, Y.; Chen, Z.; Jia, J.; Bao, X. Heavy metals and lead isotopes in soils, road dust and leafy vegetables and health risks via vegetable consumption in the industrial areas of Shanghai, China. Sci. Total Environ. 2018, 619-620, 1349-1357. [CrossRef]

3. Su, C.; Jiang, L.Q.; Zhang, W.J. A review on heavy metal contamination in the soil worldwide: Situation, impact and remediation techniques. Environ. Skept. Crit. 2014, 3, 24-38.

4. Commission of the European Communities. Commission Regulation (EC) No 1881/2006 of 19 December 2006 setting maximum levels for certain contaminants in foodstuffs. Off. J. Eur. Union 2006, L364, 5-24.

5. Peralta-Videa, J.R.; Lopez, M.L.; Narayan, M.; Saupe, G.; Gardea-Torresdey, J. The biochemistry of environmental heavy metal uptake by plants: Implications for the food chain. Int. J. Biochem. Cell Biol. 2009, 41, 1665-1677. [CrossRef]

6. Vollmannová, A.; Margitanová, E.; Kujovský, M.; Čičová, I. Risk of cadmium and lead transfer from the soil into seeds of chosen minor plants. Environ. Prot. Nat. Resour. 2013, 24, 17-20. [CrossRef]

7. Cao, X.; Wang, X.; Tong, W.; Gurajala, H.K.; Lu, M.; Hamid, Y.; Feng, Y.; He, Z.; Yang, X. Distribution, availability and translocation of heavy metals in soil-oilseed rape (Brassica napus L.) system related to soil properties. Environ. Pol. 2019, 252, 733-741. [CrossRef]

8. Korzeniowska, J.; Stanisławska-Glubiak, E.; Mickiewicz, A. Comparison of the usefulness of miscanthus, spartina and Jerusalem artichoke for phytoremediation of soils contaminated with nickel. Prog. Plant Prot. 2017, 57, 225-233. [CrossRef]

9. Kaplan, N.O.; Akay, A. The determination of Cd and Zn phytoremediation potential of buckwheat (Fagopyrum esculentum). Desalin. Water Treat. 2018, 133, 146-152. [CrossRef]

10. Harada, H.; Hatanaka, T. Natural background levels of trace elements in wild plants: Variation and distribution in plant species. Soil Sci. Plant Nutr. 2000, 46, 117-125. [CrossRef]

11. Kabała, C.; Charzyński, P.; Chodorowski, J.; Drewnik, M.; Glina, B.; Greinert, A.; Hulisz, P.; Jankowski, M.; Jonczak, J.; Łabaz, B.; et al. Polish Soil Classification, 6th edition-Principles, classification scheme and correlations. Soil Sci. Annu. 2019, 70, 71-97. [CrossRef]

12. Kara, N. Yield and mineral nutrition content of buckwheat (Fagopyrum esculentum Moench): The effect of harvest times. SDU J. Fac. Agric./Süleyman Demirel Üniv. Ziraat Fakültesi Derg. 2014, 9, 85-94. 
13. Verma, K.C.; Rana, A.S.; Joshi, N.; Bhatt, D. Review on common buckwheat (Fagopyrum esculentum Moench): A potent Himalayan crop. Ann. Phytomed. 2020, 9, 125-133. [CrossRef]

14. Mizuno, T.; Nakagawa, M.; Ono, H.; Sugiura, D.; Tamura, H.; Obata, H. Isolation of multidrug resistance associated protein like gene from lead hyperaccumulator common buckwheat and its lead detoxification ability. Plant Biotechnol. 2010, $27,39-46$. [CrossRef]

15. Ociepa, E.; Lach, J. Evaluation of the influence of organo-mineral fertilizer on the uptake of zinc, cadmium and lead and on the buckwheat crop. Environ. Prot. Eng. 2004, 30, 03-111.

16. Feng, C.; Chen, Y.; Zhang, S.; Wang, G.; Zhong, Q.; Zhou, W.; Xu, X.; Li, T. Removal of lead, zinc and cadmium from contaminated soils with two plant extracts: Mechanism and potential risks. Ecotoxicol. Environ. Saf. 2020, 187, 109829. [CrossRef] [PubMed]

17. Mitrus, J.; Horbowicz, M. Impact of short-term exposure to lead and cadmium of common buckwheat (Fagopyrum esculentum Moench) seedlings grown in hydroponic culture. J. Elem. 2020, 25, 633-644. [CrossRef]

18. Wang, L.; Zheng, B.; Yuan, Y.; Chen, P. Transcriptome profiling of Fagopyrum tataricum leaves in response to lead stress. BMC Plant Biol. 2020, 20, 54. [CrossRef] [PubMed]

19. Pohontu, C.M. Rehabilitation of degraded soils containing Lead $\left(\mathrm{Pb}^{2+}\right)$ ions based on phytoremediation with Fagopyrum esculentum Moench in presence of Ethylene-diamine-tetracetic acid (EDTA). In Advances in Environment, Ecosystems and Sustainable Tourism; Wseas LLC, WSEAS (Organization): Brasov, Romania, 2013; pp. 84-96. ISBN 978-1-61804-195-1.

20. Tamura, H.; Honda, M.; Sato, S.; Kamachi, H. Pb hyperaccumulation and tolerance in common buckwheat (Fagopyrum Esculentum). J. Plant Res. 2005, 118, 355-359. [CrossRef]

21. Tani, F.H.; Barrington, S. Zinc and copper uptake by plants under two transpiration rates. Part II. Buckwheat (Fagopyrum esculentum L.). Environ. Pollut. 2005, 138, 548-558. [CrossRef] [PubMed]

22. Shen, R.F.; Chen, R.F.; Ma, J.F. Buckwheat accumulates aluminum in leaves but not in seeds. Plant Soil 2006, $284,265-271$. [CrossRef]

23. Shen, R.; Ma, J.F.; Kyo, M.; Iwashita, T. Compartmentation of aluminium in leaves of an Al-accumulator, Fagopyrum Esculentum Moench. Planta 2002, 215, 394-398. [CrossRef] [PubMed]

24. Lu, Y.; Wang, Q.F.; Li, J.; Xiong, J.; Zhou, L.N.; He, S.L.; Zhang, J.Q.; Chen, Z.A.; He, S.G.; Liu, H. Effects of exogenous sulfur on alleviating cadmium stress in tartary buckwheat. Sci. Rep. 2019, 9, 7397. [CrossRef]

25. Pirzadah, T.B.; Malik, B.; Tahir, I.; Rehman, R.; Hakeem, K.R.; Alharby, H.F. Aluminium stress modulates the osmolytes and enzyme defense system in Fagopyrum species. Plant Physiol. Biochem. 2019, 144, 178-186. [CrossRef]

26. Braud, A.M.; Gaudin, P.; Hazotte, A.; Le Guern, C.; Lebeau, T. Chelate-assisted phytoextraction of lead using Fagopyrum esculentum: Laboratory vs. field experiments. Int. J. Phytoremed. 2019, 21, 1072-1079. [CrossRef] [PubMed]

27. Alves, J.C.; Souza, A.P.; Pôrto, M.L.; Fontes, R.L.F.; Arruda, J.; Marques, L.F. Potential of sunflower, castor bean, common buckwheat and vetiver as lead phytoaccumulators. Rev. Bras. Eng. Agric. Ambient. 2016, 20, 243-249. [CrossRef]

28. Franzaring, J.; Damsohn, W.; Fangmeier, A.; Schlosser, S.; Kurz, H.; Büttner, P. Phytotoxicity of tin mine waste and accumulation of involved heavy metals in common buckwheat (Fagopyrum esculentum Moench). Int. J. Phytoremed. 2018, 20, 462-470. [CrossRef]

29. Awad, M.; Liu, Z.; Skalicky, M.; Dessoky, E.S.; Brestic, M.; Mbarki, S.; Rastogi, A.; El Sabagh, A. Fractionation of Heavy Metals in Multi-Contaminated Soil Treated with Biochar Using the Sequential Extraction Procedure. Biomolecules 2021, 11, 448. [CrossRef]

30. Sharma, A.; Sidhu, G.; Araniti, F.; Bali, A.S.; Shahzad, B.; Tripathi, D.K.; Brestic, M.; Skalicky, M.; Landi, M. The Role of Salicylic Acid in Plants Exposed to Heavy Metals. Molecules 2020, 25, 540. [CrossRef]

31. Liu, Z.; Ding, Y.; Wang, F.; Ye, Y.; Zhu, C. Role of salicylic acid in resistance to cadmium stress in plants. Plant Cell Rep. 2016, 35, 719-731. [CrossRef]

32. Nikolić, D.B.; Samardzić, J.T.; Bratić, A.M.; Radin, I.P.; Gavrilović, S.P.; Rausch, T.; Maksimović, V.R. Buckwheat (Fagopyrum esculentum Moench) FeMT3 gene in heavy metal stress: Protective role of the protein and inducibility of the promoter region under $\mathrm{Cu}(2+)$ and $\mathrm{Cd}(2+)$ treatments. J. Agric. Food Chem. 2010, 58, 3488-3494. [CrossRef]

33. Tuma, J.; Skalicky, M.; Tumova, L.; Flidr, J. Influence of cadmium dose and form on the yield of oat (Avena sativa L.) and the metal distribution in the plant. J. Elem. 2014, 19, 795-810. [CrossRef]

34. Singh, S.; Aggarwal, P.K. Effect of heavy metals on biomass and yield of different crop species. Indian J. Agric. Sci. 2006, 76, $688-691$.

35. Joshi, D.; Srivastava, P.C.; Srivastava, P. Toxicity threshold limits of cadmium for leafy vegetables raised on Mollisol amended with varying levels of farmyard manure. Pedologist 2011, 54, 249-256. [CrossRef]

36. Lou, Y.; Luo, H.; Hu, T.; Li, H.; Fu, J. Toxic effects, uptake, and translocation of Cd and Pb in perennial ryegrass. Ecotoxicology 2013, 22, 207-214. [CrossRef]

37. Horbowicz, M.; Dębski, H.; Wiczkowski, W.; Szawara-Nowak, D.; Koczkodaj, D.; Mitrus, J.; Sytykiewicz, H. The impact of short-term exposure to $\mathrm{Pb}$ and $\mathrm{Cd}$ on flavonoid composition and seedling growth of common buckwheat cultivars. Pol. J. Environ. Stud. 2013, 22, 1723-1730. 